Fenyves, Katalin. “Taylor, Jeff. 2014. In Search of the Budapest Secession: The Artist Proletariat and Modernism's Rise in the Hungarian Art Market, 1800-1914. Saint Helena, CA: Helena History Press; distributed by Central European University Press, Budapest. 260 pp.; Szívós, Erika. 2011. Social History of Fine Arts in Hungary, $1867-$ 1918. Boulder, CO: Social Science Monographs. 349 pp." Hungarian Cultural Studies. e-Journal of the American Hungarian Educators Association, Volume 9 (2016): http://ahea.pitt.edu DOI: 10.5195/ahea.2016.250

\title{
Taylor, Jeff. 2014. In Search of the Budapest Secession: The Artist Proletariat and Modernism's Rise in the Hungarian Art Market, 1800-1914. Saint Helena, CA: Helena History Press; distributed by Central European University Press, Budapest. 260 pp.; Szívós, Erika. 2011. Social History of Fine Arts in Hungary, 1867-1918. Boulder, CO: Social Science Monographs. 349 pp.
}

\author{
Reviewed by Katalin Fenyves, Budapest Metropolitan University
}

With the publication of Jeff Taylor's 2014 book that delineates the emergence and development of the art market in Hungary from 1800 to 1914, the last missing piece to complete a new narrative of the Hungarian art scene fell into place. Taylor's study ought to be read like a much welcome sequel to Erika Szívós's 2011 book, which gave a thorough quantitative and qualitative analysis of the most important agencies of the Hungarian art world between 1867 and 1918. Academics and students can now relish in a history of the early modern fine arts in Hungary that is solidly grounded in social reality; this double achievement was made possible thanks to the efforts of an array of researchers and mainly Ilona Sármány-Parsons, the advisor of Jeff Taylor's and opponent of Erika Szívós's doctoral theses.

While in the wake of Robert Jensen's seminal work, Marketing Modernism in Fin-deSiècle Europe (Princeton, N.J.: Princeton UP, 1994), Taylor's theoretical focus is the "conflict between an artist proletariat and the Secession's elites" (Jensen, Marketing Modernism, Princeton UP paperback edition, 1996, 201), a conflict that led to the formation and later the break of several artists movements fighting relentlessly for recognition in the form of available wall space, Szívós starts out by debunking the myth of the bohemian artist. Fortunately, both researchers did a lot more than this. Letting go at some point in his book of the idea of an artist proletariat, Taylor proceeds to tell an easy-to-follow, linear story of the emergence of the art market "in an essentially German-speaking provincial capital in a German-speaking empire" (1), whereas Szívós gives a well-documented overview of the major stakeholders of the turn-of-the century Hungarian art scene.

The story of the Hungarian art market as told by Taylor sets out in a similar way to that of nineteenth-century Vienna, with some immigrants peddling sheet music, graphics and maps, and subsequently with the arrival of some lithographers who used a new technology to produce cheaper prints and illustrations. These lithographers also sold and resold art works, but Pest was then still a provincial town and the number of its buyers remained insignificant. In that situation, the first breakthrough, the establishment of the Pesti Müegylet ('The Pest Art Society') in 1839 was above all a political act, as the Society was to achieve important goals related to the Hungarian national-romantic identity for which the young liberals stood up: to educate a buying

(cc) BY

ULLS D-Serle
New articles in this journal are licensed under a Creative Commons Attribution 4.0 International License.

This journal is published by the University Library System of the University of Pittsburgh as part of its D-Scribe Digital Publishing Program and is cosponsored by the University of Pittsburgh Press 
Fenyves, Katalin. “Taylor, Jeff. 2014. In Search of the Budapest Secession: The Artist Proletariat and Modernism's Rise in the Hungarian Art Market, 1800-1914. Saint Helena, CA: Helena History Press; distributed by Central European University Press, Budapest. 260 pp.; Szívós, Erika. 2011. Social History of Fine Arts in Hungary, 18671918. Boulder, CO: Social Science Monographs. 349 pp.” Hungarian Cultural Studies. e-Journal of the American Hungarian Educators Association, Volume 9 (2016): http://ahea.pitt.edu DOI: 10.5195/ahea.2016.250

public, to support young artists and try to keep the better-known masters from leaving the country. The first show organized by the Pest Art Society opened in 1840, and the Society, which never had a permanent exhibition space, went on operating, exhibiting works by Hungarian and non-Hungarian artists and using raffles (a lottery in which the prizes were art works), until 1859, when a group of dissatisfied painters started to discuss the creation of a new organization. The cause of frustration of these artists was twofold: too many non-Hungarian artists competing with the local ones and the raffle system, both of which prevented Hungarian artists from selling their works directly to a still rather limited public.

Due to difficulties raised by the Royal Council of the Governor ('Helytartótanács'), the new organization, the National Hungarian Fine Arts Society ('Országos Magyar Képzömüvészeti Társulat, $O M K T^{\prime}$ ), started to function only around 1863 but by 1868 it totally eclipsed its predecessor Society. According to Taylor, from this time and on the always new secessionists brought about a succession of "elitist" and "democratic" movements whose members were competing for making a living as artists: "The battles of nineteenth- and early twentieth-century art politics always revolved around the same inescapable scarcity of exhibition space and the same unavoidable quandary of deciding which artworks would fill it" (188). What might have seemed an antagonism between the Conservatives and the Modernists, was -- according to many of their contemporaries -- a conflict between the aristocrats of true art and the representatives of group mentality. Or, as one of the newspapers of the time put it: "Camaraderie and bread over artistic perspective. Bad artists over good artists" (189). According to Taylor, all these fights ultimately led to the end of the Salon system and the victory of the dealer.

In his Conclusion, Taylor argues that "the Salon model was kept on life-support by the Communist regimes of Eastern Europe, but even then its decision-making structure... reflected a top-down, state-command economy. This system only met its belated death in the early 1990s, and by then galleries on the Modernist model had resumed their activity" (189). This depiction might be challenged, but later in the same concluding part Taylor himself points at the inadequacies of the Hungarian art market and discusses the economic reality that was hardly hidden by the fights over exhibition space: "from 1840 until 1910, private collectors purchasing routinely represented less than half of the buying at the Salons. Until 1910, the state was required to make more than $50 \%$ of the purchases at the OMKT. (...) Ultimately, the problem lay in the slow and insufficient development of a middle-class buying public" (191).

During the Dualist Era, with a middle-class buying public that was never numerous enough, beside the artists themselves, the state was the most important stakeholder in the arts. In her book -- whose 2011 English edition merits much international attention -- Erika Szívós accordingly deals with the state's role in developing the Hungarian art market. Art played a prominent role in the nation-building process after the Compromise of 1867, in which the Dual Monarchy was formed and the Hungarian Kingdom was no longer subject to the Austrian Empire. A crucial factor in the creation of a common symbolic culture in the multiethnic country, art was also meant to be a primary tool in the education of the public. Hence the establishment of schools and master schools for painting, architecture and design, the stipends for students turning to these fields, the construction of museums and -- above all -- the abundant state-commissioned generous purchases of art works. 
Fenyves, Katalin. “Taylor, Jeff. 2014. In Search of the Budapest Secession: The Artist Proletariat and Modernism's Rise in the Hungarian Art Market, 1800-1914. Saint Helena, CA: Helena History Press; distributed by Central European University Press, Budapest. 260 pp.; Szívós, Erika. 2011. Social History of Fine Arts in Hungary, 18671918. Boulder, CO: Social Science Monographs. 349 pp.” Hungarian Cultural Studies. e-Journal of the American Hungarian Educators Association, Volume 9 (2016): http://ahea.pitt.edu DOI: 10.5195/ahea.2016.250

National and artistic aspirations achieved a remarkable harmony even after the turn of the century, when the Modernist movements started to claim more autonomy. By that time, as Szívós convincingly demonstrates, far from being marginal Bohemians, artists in Hungary belonged to the middle classes and some of them enjoyed considerable prestige. The second part of Szívós's study is an impressive exploration of the process of professionalization of artists, and in it she shows how social conditions and financial opportunities for artists developed in the Dualist era. To reconstruct the life path of four hundred and twenty six artists, of which forty-one were women, the author used a wide range of source materials including questionnaires of the time and of later periods, Gyula Szentiványi and János Szendrei's Artist Encyclopedia (1915) and varied research for quantitative evidence, as well as ego-documents (autobiographies, memoirs, letters) for qualitative analysis. In her original and groundbreaking research, Szívós also mapped out the whole social world of the time's art scene with its institutions, organizations, actors, and press, as well as compared the education, income, prestige, living conditions and family statuses of artists as opposed to persons of other professions. Very valuable contributions to a new history of the fine arts in Hungary, the two books, by Jeff Taylor and by Erika Szívós, are not only meritorious and capturing in themselves but they also serve as a solid base to future researches of Hungarian art and culture in the Long Nineteenth Century and, more specifically, in the Dualistic Era. 